\title{
Features and Peculiarities of the Russian Passenger Rail Market Development
}

\author{
Razumovskaya E.M.
}

Institute of Management and Territorial development, Kazan (Volga region) Federal University)

Lapidus L.V.

Lomonosov Moscow State University, Department of Economics of the social sphere

Mishakin T.S.

Institute of Management and Territorial development, Kazan (Volga region) Federal University

Popov M.L

Institute of Management and Territorial development, Kazan (Volga region) Federal University

\section{Doi:10.5901/mjss.2014.v5n18p165}

\section{Abstract}

The article describes the process of forming a passenger rail transport market in Russia and its division into market segments. Specific factors of competitive environment, the main characteristics of passenger rail transport market in Russia, the state regulation of tariffs for passenger railway transport and subsidization of tariffs for the use of rail infrastructure of public transport were considered. The main attention is devoted to innovative trends in the development of passenger rail market, including high-speed transport.

Keywords: passenger railway transportation, railway market in Russia, railway transport, long-distance and suburban trains, government regulation, tariff policy, transport strategy, high-speed rail transportation, multimodal transportation.

\section{Introduction}

The market of passenger-railway traffic in the Russian Federation is the youngest. Its formation dates back to 2003. At that time the JSCo "Russian Railways" (RZD) was founded. As a result it obtained all managing functions from Ministry of Railways (MPS). Soon Ministry of Railways (MPS) passed the state regulation functions to the Ministry of Transport and to the Federal Agency for Railway Transport (Roszheldor). [10, 11] Separate department of the Federal Service for Transport Supervision (Goszhelnadzor) keeps rail transport under control. During the following years the formation of the market was accompanied by division into market segments on categories (long-distance, suburban, international, and separately - high-speed) and the opening of access for appearance of private owners and the operators of rolling stock. The main problem that the "Russian railways" faced at the beginning of the XXI century was out-of-date infrastructure and timeworn rolling stock. In fact they have not been updated since the late 80's.

\section{Method}

The study of the specific factors of competitive environment, the main characteristics of passenger rail transport market in Russia was conducted on the basis of desk research: historical analysis, content analysis of JSC "Russian railways" key documents, benchmarking and system approach. 


\section{Results}

In the early 2000s JSC "Russian railways" has allocated a long-distance passenger transportation in specialized Federal Passenger Directorate (FPD) in order to create of conditions for the growth of transport efficiency. Along with the JSC "Russian railways" has transfered to FPD property of passenger long-distance complex (cars, repair and maintenance depot, as well as personnel of passenger traffic services). The FPD has been converted into a subsidiary of JSC "Russian railways" - JSC "Federal Passenger Company" (FPC). Furthermore, JSC "Russian railways" owns 99,99\% of shares in JSC "Federal Passenger Company" (FPC).

2005 was marked by a significant event - a new company appeared in the market of railway passenger transportations. It offered two private trains "Grand Express" (ZAO TC Grand Service Express), consisting of 13 carriages of premium luxury class on route Moscow-Saint Petersburg. 9 hours' of travel time, spacious double suites with a bathroom and warmed-up floors. The sum of investments of 100 million dollars was announced in the media. Only in three-four years JSC "Russian railways" could offer a similar service in the best branded trains. In 2011 the share of rail passenger market of Grand Service Express amounted to 0,12\%.

In 2007 JSC "Russian Railways" acquired indirect control over 25\% of the capital of ZAO "Transmashholding", one of the largest providers of fleet of locomotives, wagons and machinery for the Railways. ZAO "Transmashholding" possesses the monopolist - Tverskoi carriage-building plant. In the same period, the company "Aeroexpress" appeared on the passenger rail transport. This company provides passenger rail transport service between the city centers and major airports JSC "Transklasservis" was established in 2009, the main activity of which were long-distance passenger rail transport services.

The Emergence in 2009 of the high-speed trains "Sapsan" on routes "Moscow-St. Petersburg" and "MoscowNizhny Novgorod" became a break in development of the market. The trains produced by corporation "Siemens" on average run at a speed of $160 \mathrm{~km} / \mathrm{h}$, gaining speed on some parts up to $250 \mathrm{~km} / \mathrm{h}$. In 2010 trains of the French producer - Alstom were purchased to operate on the route Saint Petersburg - Helsinki with speed $220 \mathrm{~km} / \mathrm{h}$.

JSC "Russian Railways" was decided to create a new luxury train "Swallow" (Lastochka), produced by German manufacturer Siemens AG in period of preparation for the 2014 Olympic Games in Sochi. The design of this train should be finalized in accordance to Russian conditions of exploitation. Currently, the production of these trains are localized on Russian enterprises of the Ural region and they have become the basis of comfortable commuter traffic communication in the near decade.

Today, according to "The strategy of innovative development of JSC "Russian Railways" till 2015" the JSC "Russian Railways" (White Paper JSC "Russian Railways") is the largest backbone element of the Russian economy, the most important element of the transport system of the country, ensures more than $40 \%$ of the freight turnover (including pipeline transport) and over 35\% of the passenger turnover in the Russia» [9, p. 3]. During the reform period with capital of JSC "Russian Railways" was created more than 100 subsidiaries and affiliates, among which "Federal Passenger Company" (since 2010 - the main monopolist in the long-distance passenger transportation), JSC "Federal freight company", etc. Moreover, the JSC "Russian Railways" owns shares (of minority and blocking) in number of transport companies and seaports. Today Russian railways network includes 16 regional railways (branches), that serve as regional centers of corporate governance. The technological integration of relevant regional directorates of the aforementioned units is in their area of responsibility [7].

The real competition exists between passenger rail traffic and road and air transport. Thus the competitiveness of long-distance passenger rail services in 2000-2011 was rather high (Fig. 1). But it was observed an increase in the share of air transport in the long-distance communication from $4.2 \%$ till $11.9 \%$ and an increase in the share of road transport in the suburban communication. By the end of 2012 the share of railway transport was $41.3 \%$ which is $3.1 \%$ more than the share of road transport and almost twice more than air transport (20.8\%). On long-distance routes all neighboring and farabroad countries are regarded as competitors in the market. The total income from all types of transportations in 2012 made 209,9 billion rubles. that was accompanied also by increase in the number of transported passengers in $6.4 \%$ and reached an amount of over a billion people. 


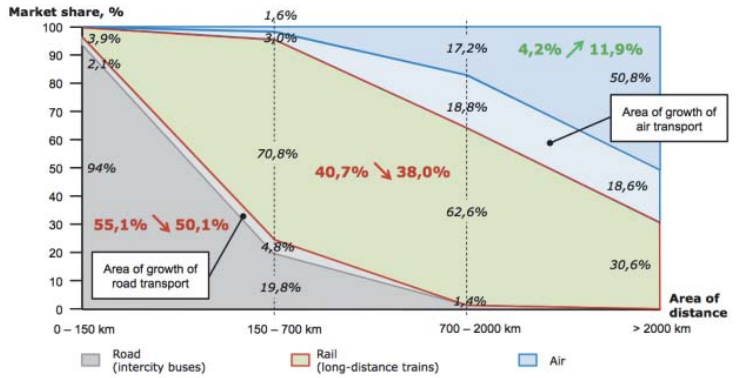

Fig. 1. Competitive capacity of railway passenger traffic in 2000-2011. Source: The Center for Strategic Research.

Despite of such development of market processes, JSC "Russian Railways" (RZD) retains a monopoly. As a whole all other market players, being private companies, as a rule have their carriages or own local railroads and have no infrastructure. Transport operation functions are carried out on the terms of lease of railways and traffic control centers and purchase of repair and test services. Along with it, RZD itself has to reduce annually fleet of trains and to leave unprofitable directions. This process is accompanied by obsolescence and lack of impact-renewal of rolling stock, so the growth rates of renewal of rolling stock for co-financing was provided in the "Russian rail transport development Strategy till 2030".

In Russia tariff policy of passenger traffic in distant traffic is formed on the basis of a combination of rigid state regulation and consecutive deregulation in segments of the transport market with the competitive environment. Tariffs for socially significant transportations in second class cars are regulated by decisions of Federal Tariff Service and provides allocation of the corresponding state subsidies at a rate of a shortfall in income. Tariffs for transportations in compartment, soft, SV cars and cars of the increased luxury comfort are established by carriers.

The tariff principle in market pricing: rail fares can expect based on the price of transportation:

$\mathrm{P}=\mathrm{c}+\mathrm{V}+\mathrm{m}$

, where P - the price of transportation; c - materialized labor costs (fuel, electricity, materials, depreciation of fixed assets); $v$ - staff labor costs (wages fund with contributions); $m$ - the surplus value created by living labor.

It is impossible to calculate the tariffs in the regulated segment in Russia by this formula, because of passenger rail transportation are unprofitable, and tariffs have a social constraint. In this case the difference between economically justified tariffs and established tariffs is compensated by state. «The principle of formation of a passenger tariff allows to bring the train to profitable level only on condition of providing an average set of the train not less than 14 cars and average use of capacity of the car not less than 70\%». [2] The dependence of the cost of long-distance passenger transport from a use of capacity of the car for the prospective period is given by:

$C=K f+K v / P C^{\prime}$

, where $K f$ - the ratio of fixed costs; $K v$ - the ratio of variable costs; $P c$ - a use of capacity of the car.

Consequently, an increase in a use of capacity of the car under $1 \%$ transportation costs will decrease by $0.39 \%$.

During 2001-2010 in the market of suburban passenger traffic for improvement of the market relations 26 suburban passenger companies (SPC) in an organizational and legal form of joint stock company with individual share of regional authorities and JSC "Russian Railways" was created. Such partnership provides establishment of balance of the state and commercial interests in the sphere of socially significant suburban transportations. According to the accepted conditions, regions have to compensate a shortfall in income of a carrier, which are formed as a result of establishment of tariffs at level below the economically reasonable.

Financial deficiency from suburban passenger transportation according to the results of 2013 is expected to be about 25 billion rubles. 36 Russian Federation constituents compensate no more than $50 \%$ of a shortfall in income of transport operators, 4 regions didn't provide the compensation... [1, 11, 12] This situation has developed because of a shortage of regional budgets, due to the imperfections of intergovernmental relations, excluding specific features solvency of consumers and the level of traffic flow in different directions (Fig. 2). 


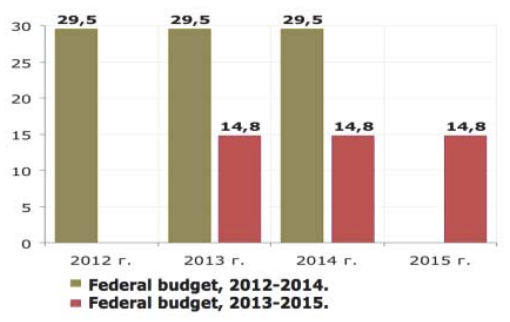

Fig. 2. The volume of subsidies for compensation of a shortfall in income for 2012-2015 according to the federal budget, billion rubles.

Source: Akulov. The Management Board of JSC "Russian Railways" for 2012. «Passenger complex of Holding. Results and development prospects».

For regulation of the organizational and economic relations in implementation of suburban rail transportation of JSC "Russian Railways" accepts normative documents in the form of the Program of development of intracity passenger traffic by a railway rolling stock of December 13, 2012 No. 381, the Programs of stage-by-stage increase of route speeds of movement of passenger trains of distant following and the suburban message of December 14, 2012 No. 2578r and the Programs of development of station infrastructure of a passenger complex of JSC "Russian Railways" on prospect till 2020 of December 20, 2012 No. 399. It should be noted that the total amount of investments of JSC "Russian Railways" in a suburban complex for 2008-2015 is planned at the level of 200 billion rubles. The most expensive part is made by investments into a rolling stock - more than 143 billion rubles ( $72,2 \%$ from all sum). The problem of insufficient funding of passenger railway traffic will remain in the next years as well. Its decision requires the new mechanism of state regulation of tariffs for transportations of passengers and subsidizing of tariffs for services in use of infrastructure of public railway transport.

The high-speed rail (HSR) service (at speeds up to $350 \mathrm{~km} / \mathrm{h}$ ) in a separate and dedicated for this (newly constructed) railroad tracks is the main trend in the evolution of innovative passenger rail transport and an effective tool for promoting social and economic development of any country. The economy of speed involves increasing of mobility of business part of the population and it will lead to creation of conditions for reduction of disproportions between less redundant and hard deficiency regions. Moreover, reduction of time of derivation from a production activity of the active population of the country who are the main users of HSR, will allow to gain social and economic effect not less than 440 rubles on one passenger for hour. [3] Along with it, the railway transport is the most eco-friendly, "green".

Staticized in 2013 "Russian rail transport development Strategy till 2030" provides construction of HSR with a general extent of 1,5 thousand $\mathrm{km}$. The state has to assume the main obligations for financing of this innovative direction. Along with it to resolve an issue with attraction long-term (till 40 years) investments into high-speed railway communication it is possible with the help of improvement of state-private partnership and market opening for the foreign companies. The project of staticized "Russian transport development Strategy till 2030" includes the important target directions: increase of competitiveness, availability and quality of passenger traffic; ensuring availability and quality of transport services for the population according to social standards (Table 1).

Table 1. Quality of transport services to the population in accordance to social standards (innovative scenario / energy and raw materials scenario) [6, pp. 220-221]

\begin{tabular}{|c|c|c|c|c|c|c|c|c|}
\hline ondic & Unit & 2010 & 2011 & 2015 & 2018 & 2020 & 2024 & 2030 \\
\hline \multicolumn{9}{|c|}{ First-level indicators } \\
\hline \begin{tabular}{l|l}
1. & $\begin{array}{l}\text { Mobility of the population by mode of } \\
\text { transport, total: }\end{array}$ \\
\end{tabular} & \multirow{2}{*}{$\begin{array}{l}\text { pass.km } \\
1 \text { pers. per } \\
\text { year }\end{array}$} & $\begin{array}{l}6564 l \\
6564 \\
\end{array}$ & $\begin{array}{l}6916 / \\
6916\end{array}$ & $\begin{array}{l}85271 \\
8062\end{array}$ & $\begin{array}{l}9596 / \\
9021\end{array}$ & & & 155 \\
\hline - railway trans| & & 972/ 972 & 978/978 & $\begin{array}{l}1073 / \\
1023\end{array}$ & $\begin{array}{l}1145 / \\
1054\end{array}$ & 87 & 152 & 43 \\
\hline $\begin{array}{l}\text { The share of public transport in tota } \\
\text { passenger turnover }\end{array}$ & r-cen-tage & $\begin{array}{l}51,6 / \\
51,6\end{array}$ & $\begin{array}{l}50,6 / \\
50,6\end{array}$ & $\begin{array}{l}48,9 / \\
49,0\end{array}$ & $\begin{array}{l}47,8 / \\
48,1\end{array}$ & $47,2 / 47,6$ & $45,8 / 45,4$ & $43,8 / 44,7$ \\
\hline
\end{tabular}

Source: The project of staticized "Russian transport development Strategy till 2030". [4] 
Expected results of realization of the "Russian rail transport development Strategy till 2030" illustrate positive dynamics of development. [5, 8] So, "possibilities of citizens in movement will be significantly improved (Table 2). At growth of a passenger turnover by $33 \%$ quality indicators of passenger traffic will be significantly improved. Creation of the highspeed passenger traffic (with speeds up to $350 \mathrm{~km} / \mathrm{h}$ ) which range by 2030 at an exit to the maximum option of development will exceed 1,5 thousand $\mathrm{km}$ is planned. For the solution of problems of increase of transport security and improvement of transport service of economy and the country population on the maximum option for 2008 - 2030 it is necessary to invest about 13,8 trillion rubles in development of railway transport of the general and uncommon using, including for 2008 - 2015 - 5,2 trillion rubles and for 2016 - 2030 - 8,6 trillion rubles. ... During Strategy realization taking into account payback periods of projects the multiplicative effect for all economy of the Russian Federation will make about 40 trillion rubles. ... growth of an internal gross product by 4,5 times and industrial production by 3,3 times, and also for optimization of structure of economy and development of new industrial regions" will be created".

Table 2. The average age of passenger general use vehicles (innovative scenario = energy and raw materials scenario) [6, pp. 220-221]

\begin{tabular}{|c|l|l|c|c|c|c|c|c|c|}
\hline № & Indicators & Unit & 2010 & 2011 & 2015 & 2018 & 2020 & 2024 & 2030 \\
\hline 1. & Passenger cars & \multirow{2}{*}{ years } & 18 & 18 & 18 & 17 & 17 & 16 & 15 \\
\cline { 5 - 11 } & & 22,5 & 23,8 & 20,9 & 20,2 & 19,7 & 18,8 & 17,4 \\
\hline
\end{tabular}

Source: The project of staticized "Russian transport development Strategy till 2030". [4]

There is an increase of efficiency of a passenger complex on the basis of growth of productivity of equipment and a manpower, orientation to high quality and satisfaction of consumers of services, development of new types of service and routes, cooperation deepening with the foreign railway companies among the priority directions of further development of JSC "Russian Railways". Another strategic tasks are construction or allocation of specialized railway lines for the passenger traffic, development of the multimodal transportations, which main objective to provide the greatest comfort and simplicity of movement of passengers at the expense of integration of various means of transport into a uniform chain of stages of process of rendering transport service in delivery of the passenger from point $A$ in point $B$ is required.

Partial privatization of JSC "Russian Railways" is provided along with other large state corporations and holdings,. This process will include sale of $5 \%$ of actions of corporation to the state investment funds at the first stage: To pension fund and Fund of future generations. Thus, the equity stake, having changed the owner, will remain under state control. Further, after 2015 full privatization to 25\% minus one action of JSC "Russian Railways" is possible. Main objective of privatization - strengthening of market mechanisms of management and decrease in an exclusive position of company in branch, and as formation of non-state sources of financing of railway infrastructure.

\section{Conclusion}

In conclusion, it can be concluded that it is impossible to increase mobility of the population, to increase volumes of transport services for the population and to compete with the world on extent of civilization development without innovative development of this field, lag, and even ignoring of considerable world trends. Therefore "Russian transport development Strategy till 2030" has to be implemented according to the maximum scenario of innovative development, rather than according to the habitual for country scenario focused on resource and raw development.

\section{References}

Akulov, M.P. To say a word about long-distance // Technique of railways. 2013. №2.

Bagautdinova, N.G., Murtazina, G.R., Fazlieva, E.P., Naida, A.M. Improvement of the regional management system using the labor potential index // World Applied Sciences Journal, 27(1), 2013, 107-111.

Gafurov I.R., Bagautdinova N.G., Panasyuk M.V. Analysis of Strategic Perspectives of Competitiveness of Kazan // Recent Researches in Urban Sustainability, Architecture and Structures. Proceedings of the 2nd International Conference on Sustainable Cities, Urban Sustainability and Transportation (SCUST'13). Baltimore, MD, USA, September 17-19, 2013. - Baltimore: WSEAS Press. $-2013 .-$ pp. $37-44$.

Lapidus, B.M. Socio-economic reasons to creat a high-speed rail in Russia // Bulletin of the Joint Academic Council of JSC "Russian Railways". 2013. №2.

Misharin, A.S., Evseev, O.V. Actualization of the Russian transport development Strategy till 2030 // Transport of the Russian 
Federation. Journal is about science, economics and practice. 2013. №2 (45).

Hadiullina, G.N., Nugumanova, L.F., Bagautdinova, N.G., Averiyanov, B.A. Transformation of the households functions in the modern Russian economy // World Applied Sciences Journal, 27(13), 2013, 111-115.

Bagautdinova, N.G., Novenkova, A.Z., Sarkin, A.V. Quality management system formulation and implementation as a factor of enhancement of the university role in the local development // World Applied Sciences Journal, 27(13), 2013, 38-42.

Nagendra R. Velaga, John D. Nelson, Steve D. Wright, John H. Farrington. The Potential Role of Flexible Transport Services in Enhancing Rural Public Transport Provision. The Journal of Public Transportation. Center for Urban Transportation Research (CUTR) University of South Florida. 2012. Volume 15, №1.

Polyakova, L.V. Current condition and trends of development of passenger rail transport in Russia. The theoretical journal «Credo new», №3 (75), Volume 2, St. Petersburg 2013.

Panasyuk, M.V., Dzasaeva, R.D., Shaidullin, R.N., Anopchenko, T.Y. Problems of modernization of the health economics in the russian regions // World Applied Sciences Journal, 27(13), 2013, 154-158.

Safiullin L.N., Ismagilova G.N., Gallyamova D.Kh., Safiullin N.Z. 2013. Consumer benefit in the competitive market // Procedia Economic and finance. Volume 5, pp. 667-676 (DOI: 10.1016/S2212-5671(13)00078-6).

"Russian rail transport development Strategy till 2030", by the Federal Government from 17.06.2008 № 887-p. 